\title{
THE INFLUENCE OF LIFE STYLE AND POSITIVE EMOTION ON IMPULSE BUYING AT JM SUPERMARKET PALEMBANG
}

\author{
Windiarto S.* \\ State Islamic University Raden Fatah, Palembang, South Sumatra, Indonesia \\ Azizah, Erna A.R., Djuita P., Supriadi \\ Institute of Economic Science APRIN, Palembang, South Sumatra, Indonesia \\ *E-mail: windiartosyaef@gmail.com
}

\begin{abstract}
This study aims to determine: (1) the influence of Life Style on impulse buying on customers in the JM Supermarket of Palembang City; (2) the effect of positive Emotion on Impulse buying on customers at JM Supermarket in Palembang City; (3) the effect of Life Style and Positive Emotion on impulse buying for customers at JM Supermarket in Palembang City. Study uses primary data obtained by survey methods by distributing questionnaires that have been tested for validity and reliability. The population in this study were customers at JM Supermarket in Palembang City. The sampling technique uses random sampling method with a total sample of 120 people. The data analysis technique used is multiple linear regression. Life Style has a significant effect on impulse buying JM Supermarket in Palembang city. Positive Emotion significantly affects Impulse Buying in Palembang JM Supermarket customers.
\end{abstract}

\section{KEY WORDS}

Life style, positive emotion, impulse buying, customers.

Along with lifestyle changes, consumers will always try to meet their needs. Consumer behavior to meet their needs will be related to consumer behavior. Consumer behavior will appear due to planning or without prior planning (impulse buying). Today's consumer needs continue to change, which greatly influences changes in lifestyle patterns or lifestyle.

Life Style encompasses behavioral aspects related to multi-sensory, fantasy and emotional consumption that are controlled by benefits such as pleasure in using products and aesthetic approaches (Rachmawati, 2009). According to Hausman (2000) the value of hedonic plays a significant role in impulse buying. Consumers as purchasing decision makers or influential in the decision making process need to be understood in order to generate Impluse Buying phenomena in order to increase sales. To be able to bring up the impulse buying phenomenon, marketers must know the factors that influence consumers in impulse buying. Factors that cause impulse buying include excessive consumption and positive emotions (Amiri et al., 2012). At present most consumers in Indonesia are more recreational oriented when.

The rapid development of JM Supermarket has an impact on human behavior. At this time in human behavior there has been a shift in behavior (behavior change). The behavior of people who are planned is unplanned or impulse buying. This situation is seen in the situation of JM Supermarkets that provide goods that can meet their needs (consumers) and provide benefits for them financially. They forget the purpose when they enter the shop as they should. This phenomenon occurs in the Palembang City JM Supermarket which provides many outlets in it and offers various consumer goods. Along with the development of Palembang City as one of the big cities and is expected to develop into a Metropolitan city, the existence of a comfortable and modern economic facility is a necessity for visiting citizens and tourists. Following the demands of these needs, in Palembang City also grew and developed one of them JM Supermarket. JM Supermarkets are centers that have one or more major department stores as the attraction of small retailers and restaurants with 
building typologies such as shops that face the main corridor of the JM Supermarket or pedestrian which is the main element of a center (JM Supermarket), with functions as circulation and as a communal space for the interaction between visitors and merchants (Maitland, 1987).

Based on the results of prasurvey observations, researchers can conclude that lifestyle greatly influences consumers' thinking patterns about meeting their needs. Consumers with a lifestyle will tend to be happy with everything that is luxury without thinking about prices and budgets, including in this case the purchase of fashion products. Based on the observations of researchers, showing consumers who are very easy to spend money to shop, usually will often make purchases beyond what they had planned before.

\section{LITERATURE REVIEW}

An understanding of consumer behavior and the consumption process will produce a number of benefits including helping managers to make decisions, providing basic knowledge for researchers in analyzing consumers, and helping consumers make better purchasing decisions (Dwiastuti, et al., 2012). Consumer behavior is the buying behavior of end consumers, both individuals and households, who buy products and services for personal consumption (Kotler and Armstrong, 2012). Consumer behavior is an action that is directly involved to get, consume, and spend products and services, including the decision process that precedes and follows this action (Simamora, 2008).

According to Lisda (2010) impulsive buying (impulse buying) is the process of buying an item, where the buyer has no intention to buy before, it can be said without a planned purchase or instant purchase. Whereas according to Mowen and Minor (2002) impulse purchase is an act of buying that was not previously recognized consciously as a result of a consideration, or buying intention that was formed before entering the store. It is clear by the opinion of Rook and Fisher (1995) that impulsive buying is defined as the tendency of consumers to buy spontaneously, reflexively, suddenly, and automatically. It can be said that impulse buying is a natural and fast reaction.

Sutisna (2002) explains that impulsive purchases occur when consumers take sudden purchase decisions. The drive to make purchases is so strong that consumers no longer think rationally about their purchases. According to Park (2006) impulsive purchases often appear suddenly, quickly, spontaneously, more toward emotional rather than rational, more often regarded as something worse than something good, and consumers tend to feel "outof-control" when buying goods impulsively. In line with the opinion expressed by Schiffman and Kanuk (2007) that impulsive buying is an emotional decision or according to the insistence of the heart. Emotions can be very strong and apply as the basis for a dominant purchase motive.

Lifestyle refers to how a person lives, how they spend their time and money, their purchasing activities, their attitudes and opinions about the world in which they live (Kotler and Keller, 2012). Aperson's lifestyle can be shown by looking at his opinions on a particular object. A person's lifestyle is a pattern of life in the world that is expressed by one's activities, interests, and income. lifestyle is defined as the behavior shown by the customer in connection with a series of personal responses and opinions about product purchases (Tirmizi, 2009). The way we shop reflects status, dignity and habits. lifestyle shows the way a person chooses to allocate income, both in terms of fund allocation for various products and services, and certain alternatives in differentiating similar categories (Japarianto, 2010).

Emotions which include feelings and moods (mood) are important factors in making decisions by consumers (Park, Kim, \& Forney, 2006). Emotions can be divided into two dimensions, namely positive and negative. Positive emotions can be seen through positive feelings such as happy, loving, liking, enjoying, satisfied, and alert.

Positive creation emotion to consumers about a product or article or even the store environment can improve consumers' motives in impulse buying. According to Peter and Olson (2005) states that the main store atmosphereter involves affection in the form of emotion in a store that is possible without being fully realized by the customer while. 
The basic model underlying Donovan and Rositter's research, is taken from the environmental psychological literature. Basically, the model states that environmental stimuli affect the emotional status of customers, which in turn will influence behavior or become a customer. Approaching behavior is a movement towards and avoidance behavior is a movement away from various kinds of environment and stimuli.

\section{METHODS OF RESEARCH}

This study uses multiple linear regression analysis techniques, to test whether there is a relationship between the independent Life Style $\left(X_{1}\right)$, Positive Emotions $\left(X_{2}\right)$ independent variables, and Impulse Buying $(\mathrm{Y})$ dependent variable.The regression equation in this study is as follows:

$$
Y=a+\beta_{1} X_{1}+\beta_{2} X_{2}+e
$$

Where: $A=$ Constanta; $\beta 1 \beta 2=$ Variable Regression Coefficients $X 1$ and $X 2 ; X 1=$ Life Style; $\mathrm{X} 2$ = Positive Emotion; $\mathrm{Y}=$ Impulse Buying; $\mathrm{e}=$ Standard error.

\section{DISCUSSION OF RESULTS}

Regression models do not experience multicollinearity disorders, this can be seen in the tolerance value of each variable greater than 10 percent $(0.1)$. VIF calculation results also show that the VIF value of each variable is less than 10 . So it can be concluded that there is no multicollinearity between the independent variables in the regression model. The following table shows the results of multicolinearity tests:

Table 1 - Multicolinearity Test

\begin{tabular}{ccc}
\hline Variable & Tolerance & VIF \\
\hline Life Style & 0,970 & 1,081 \\
\hline Positive Emotion & 0,970 & 1,081 \\
\hline
\end{tabular}

Source: Data Processed, 2019.

Table 2 - Autocorrelation Test

\begin{tabular}{cc}
\hline Variable & Significant Result \\
\hline Durbin Watson & 1,403 \\
\hline
\end{tabular}

Source: Data Processed, 2019.

Durbin Watson's value is between -2 to 2 , meaning that there is no autocorrelation problem (Santoso, 2012).

Table 3 - Test Results t

\begin{tabular}{cc}
\hline Variable & Significant \\
\hline Life Style & 0.001 \\
\hline Positive Emotion & 0.012 \\
\hline
\end{tabular}

Source: Data Processed, 2019.

In the Life Style variable with a significance level of $95 \%(\alpha=0.05)$. The significance value ( $P$ Value) on the Life Style variable is $0.001<0.05$. On the basis of these comparisons, $\mathrm{HO}$ is rejected or means that the Life Style variable has a significant effect on Impluse Buying variables.

In the Positive Emotion variable with a significance level of $95 \%(\alpha=0.05)$. The number of significance ( $P$ Value) on the variable is $0.012<0.05$. On the basis of these comparisons, $\mathrm{HO}$ is rejected or means that Positive Emotion variables has a significant effect on Impluse Buying variables. 
Table 4 - Test F

\begin{tabular}{cccccc}
\hline Model & Sum of & D & Mean & F & Sig \\
\hline Regression & 608.750 & 2 & 304.375 & 27.447 & $.000^{\mathrm{b}}$ \\
\hline Residual & 1630.190 & 117 & 11.090 & & \\
\hline Total & 2238.940 & 119 & & & \\
\hline
\end{tabular}

Sources: Data Processed, 2019.

The calculated $F$ value is 11,186 with a significance value ( $P$ value) of 0,000 . With a $95 \%$ significance level $(\alpha=0.05)$. The significance value (P value) is $0,000<0,05$. On the basis of these comparisons, $\mathrm{H}_{0}$ is rejected or means that the Life Style and Positive Emotion variables have a significant influence on the Impluse Buying variable.

Table 5 - Determinantion Coefficient

\begin{tabular}{ccccc}
\hline Model & $\mathrm{R}$ & $\mathrm{R}$ Square & Adjusted R Square & Std. Error of the Estimate \\
\hline 1 & $.621^{\mathrm{a}}$ & .472 & .362 & 4.330 \\
\hline
\end{tabular}

Sources: Data Processed, 2019.

In table 6 it can be seen that the value of adjusted $R$ Square is 0.362 . This means that the independent variable ( Life Style and Positive Emotion) can explain the dependent variable (Impulse Buying) by $36,2 \%$, while the rest is explained by other factors that are not examined.

Table 6 Regression Coefficient

\begin{tabular}{ccc}
\hline Model & B & Std \\
\hline Constant & 12.805 & 2.581 \\
\hline Life Style & .399 & .061 \\
\hline Positive Emotion & .487 & .083 \\
\hline
\end{tabular}

Sources: Data Processed, 2019.

Obtained multiple linear regression equation as follows:

$$
Y=12.805+0.399 X 1+0.487 X 2
$$

Above equation can be explained as follows:

- The value of 0.399 in the Life Style variable $\left(X_{1}\right)$ is positive so it can be said that the higher the Life Style given by the Consumer, the higher Impluse Buying will be;

- The value of 0.487 in the Positive Emotion variable $\left(X_{2}\right)$ is positive so that it can be said that the higher the Positive Emotion provided by the Consumer, also for the higher Impulse Buying.

\section{CONCLUSION}

Based on the analysis and discussion of the influence of life style variables on impulse buying through positive emotions on consumers of Palembang JM Supermarket, the following conclusions can be drawn:

- Life Style has a significant effect on impulse buying JM Supermarket in Palembang city;

- Positive Emotion has a significant affects Impulse Buying in Palembang JM Supermarket customers;

- Lifestyle variables and positive emotion have a simultaneous effect on the variable impulse buying. 


\section{REFERENCES}

1. Amiri, F., Jalal, J., Mohsen, S., and Tohid, A. (2012). Evaluation of Effective Fashionism Involvement Factors on Impulse Buying of Costumers and Condition of Interrelation between These Factor. Journal of Basic and Applied Scientific Research. 2(9), pp. 94139419.

2. Dwiastuti, R., Shinta, A., dan Isaskar, R. 2012. Ilmu Perilaku Konsumen. Malang: Universitas Brawijaya Press.

3. Hausman, Angela. 2000. A Multi- method Investigation of Consumers in Impulse Buying Behavior. Journal of Consumer Marketing, Vol. 17 Iss: 5 pp. 403- 426.

4. Japarianto, Edwin. 2010. Analisa Faktor Type Hedonic Motivation dan Faktor Pembentuk Kepuasan Tourist Shopper di Surabaya. Jurnal Manajemen dan Kewirausahaan. Vol.12 No 1, 76-85.

5. Kotler, P., dan Armstrong, G. 2012. Principles of Marketing. New Jersey: Prentice-Hall, Inc.

6. Kotler, P., dan Keller, K.L. 2012. Marketing Management. New Jersey: Pearson Education, Inc.

7. Maitland, Barry. 1987. JM Supermarkets Planning and Design. London: Construction Press.

8. Ma'ruf, Hendri. 2006. Pemasaran Ritel. Gramedia Pustaka Utama: Jakarta.

9. Mowen, Jonh C \& Minor, Michael. 2002. Perilaku Konsumen Jilid 1. Alih Bahasa: Lina Salim. Jakarta: Erlangga.

10. Park, J.S., Shin, K.H, park, J.B., Lee, S. dan Hwang, S.J. (2007). Disintegrating Behaviour of A Rapidly Disintegrating Famotidine Tablet Formulation. J. Kor. Pharm. Sci. 37(5): 275-280.

11. Peter, J.Paul dan Olson Jerry C.,2005,Consumer Behavior and Marketing Strategy,5th,Singapore,The Mc, Graw Hill Companies, Inc

12. Rook, D.W. \& Fisher, R.J. 1995. Normative Influences on Impulsive Buying. Journal of Consumer Research. Vol.22.hlm. 305-313.

13. Santoso, Singgih. 2012. Panduan Lengkap SPSS Versi 20. Jakarta: PT Elex Media Komputindo.

14. Schiffman, L. G. \& Kanuk, Leslie. L. 2007. Consumer Behavior. America: Pearson Prentice Hall.

15. Simamora, B. 2008. Panduan Riset Perilaku Konsumen. Jakarta: PT Gramedia Pustaka Utama.

16. Sutisna. 2002. Perilaku Konsumen dan Komunikasi Pemasaran. Bandung: PT Remaja Rosdakarya.

17. Tirmizi, M.A. (2009). An Empirical Study of Consumer Impulse Buying Behaviour in Local Markets. European Journal of Scientific Research, Vol 28(4), 522-532. 